\title{
Prevalence of Trichomonasvaginalis Among Female Patients Attending the General Hospital Nasarawa, Nasarawa State
}

\author{
Yusuf Hussaini", Justina A. Adegda, Ademu Abdulkadir, Abubakar Suleiman, Salawu E. Murtala, \\ Yakubu Jibrin, Aliyu Yakubu
}

Department of Science Laboratory Technology, School/Faculty of Applied Sciences, Federal Polytechnic Nasarawa, Nasarawa, Nigeria

\section{Email address:}

hussainiyusuf9015@gmail.com (Y. Hussaini), attahjustina@rocktmail.com (J. A. Adegda), ademuabdulkadir@yahoo.com (A. Abdulkadir), suleiman575@yahoo.com (A. Suleiman),murtala4u2013@gmail.com (S. E. Murtala), yaqoobjibril@gmail.com (Y. Jibrin), aleeyaqoob29@gmail.com (A. Yakubu)

*Corresponding author

\section{To cite this article:}

Yusuf Hussaini, Justina A. Adegda, Ademu Abdulkadir, Abubakar Suleiman, Salawu E. Murtala, Yakubu Jibrin, Aliyu Yakubu. Prevalence of Trichomonasvaginalis Among Female Patients Attending the General Hospital Nasarawa, Nasarawa State. Cell Biology.

Vol. 5, No. 1, 2017, pp. 8-11. doi: 10.11648/j.cb.20170501.12

Received: January 10, 2017; Accepted: February 10, 2017; Published: March 18, 2017

\begin{abstract}
Trichomonasvaginalis, the etiologic agent of Trichomoniasis is transmitted by sexual intercourse, and is associated with the presence of other sexually transmitted diseases. In Nigeria, Trichomonasvaginalis infections are not reportable to health agencies and there is dearth of data on the actual prevalence. This cohort study determines the prevalence of Trichomonasvaginalis among female patients attending General Hospital Nasarawa, NasarawaState. Wet mount of all swab samples was made to check for the presence of motility. Out of 100 vaginal swabs samples analyzed, an overallprevalence of $12.0 \%$ was recorded. The highest prevalence of $16.67 \%$ was recorded for the $31-35$ years old, while the lowest prevalence of $7.67 \%$ was recorded for $16-20$ years old. $13.2 \%$ prevalence was recorded in single women while $8.70 \%$ prevalence was recorded in married women. Those with three or more sex partners had $75 \%$ prevalence, $50 \%$ prevalencewas reported for those with two sex partners, while 3.6\% was reported for those with one sex partner Trichomoniasis remained endemic in many developing countries where control may only be possible by regular screening and treatment. Sexual promiscuity and age were important predisposing factors of infection distribution in the studied population.
\end{abstract}

Keywords: Trichomoniasis, Vaginalis, Nasarawa, Prevalence

\section{Introduction}

Trichomoniasis, caused by the protozoan parasite Trichomonas vaginalis, is one of the most common curable STDs. It is estimated that there are over 3.7 million people with trichomoniasis in the United States and 1.1 million new cases each year. In women, infection with $T$. vaginalis has been suggested to be associated with adverse pregnancy outcomes, including premature rupture of membranes and pre-term labor, pelvic inflammatory disease, and increased risk for HIV infection. Based on the estimated incident cases among all ages in 2008, the total lifetime direct medical cost of trichomoniasis in the US was estimated at \$24.0 million [1-2]. In the US, Trichomonas vaginalis (TV) infections are not reportable to state agencies and therefore actual prevalence data is limited. In addition, as many as $85 \%$ of infected women ${ }^{1}$ are asymptomatic and therefore do not even undergo testing. Also, in those that are tested, the sensitivity of diagnostic tests varies widely. Trichomonasvaginalis is a flagellated protozoan that causes trichomoniasis in human. Studies have shown that Trichomonasvaginalis is one of the most prevalent sexually transmitted pathogens in the world, it has been estimated by WHO that about 170 million cases occurs every year [1]. The epidemiology of the disease is still not well understood and some medical personnel continue to doubt its importance. However, there is growing evidence that $T$ vaginalis is an important pathogen, both in its own right due to the "immediate" morbidity associated with 
infection, [2] for its role in the promotion of premature rupture of membranes, premature labor, and low birth weight, [3-4] and because of the likelihood of predisposing of HIV transmission [5-7]. While a slightly increased risk for HIV transmission may have minor significance for an individual, it may be of considerable importance at a community level [8]. Understanding the relation between $T$ vaginalis and other sexually transmitted infections would assist its use as a marker for the success of behavioral and treatment interventions targeting other STDs including HIV [9]. Few studies examine the prevalence of TV across age groups, and many are limited by the diagnostic tests previously described. A recent study (5) used real-time PCR assays and compared by age groups the rates of $\mathrm{T}$. vaginalis, $\mathrm{C}$. trachomatis and $\mathrm{N}$. gonorrhea in Florida, Texas and New Jersey [8-11].

\section{Materials and Methods}

This cohort study was carried out 100 female patients attending the General Hospital Nasarawa, Nasarawa state,
Nigeria. An informed consent was obtained from all respondents and demographic information such as age, education and occupationwere recorded in the questionnaires. High vaginal swab samples were collected by inserting a sterile speculum into the posterior fornix of the vagina while the individual is in the lithotomic position. The natures of the collected samples were noted such as the colour, consistency and odour; the samples were then put in $0.3 \mathrm{~mL}$ of sterile physiological saline. The resulting suspension was put on a clean slide, covered with a cover slip and examined immediately under the microscope. A smear of the secretion was also made on a slide, air dried and fixed in absolute methanol for $1 \mathrm{~min}$. Diluted Giemsa stain was poured on the smear and allowed to stain for $10 \mathrm{~min}$ after which it was washed, air dried and examined under the microscope. Chisquared $\left(\chi^{2}\right)$ test was used to compare $T$. vaginalis infection relative to clinical manifestations and parasitological results. Analyses were performed with SPSS (version 18; SPSS Inc, Chicago, IL, USA), with a probability $(P)$ value of $<0.05$ were considered as statistically significant.

\section{Result}

Table 1. Prevalence of T.vaginalis in Relation to Age Group.

\begin{tabular}{lllll}
\hline AgeGroup & No of samples tested & No of positive samples & Positive(\%) & ConfidenceInterval \\
\hline $16-20$ & 13 & 1 & 7.7 & $76.9-83.3$ \\
$21-25$ & 47 & 6 & 12.7 & $59.8-63.7$ \\
$26-30$ & 31 & 4 & 12.9 & $51.3-54.1$ \\
$31-35$ & 9 & 1 & 11.1 & $43.5-77.0$ \\
Total & 100 & 12 & 12.0 & $62.5-66.7$ \\
\hline
\end{tabular}

$\mathrm{X}^{2}=0.81 \mathrm{P}=0.09>0.05$

Table 2. Prevalence of T.vaginalis in Relation to the number of sex partners.

\begin{tabular}{lllll}
\hline No of sexPartners & No of samplestested & No of positivesamples & Positive (\%) & ConfidenceInterval \\
\hline One & 84 & 3 & 3.6 & $13.2-15.2$ \\
Two & 12 & 6 & 50.0 & $25.4-74.6$ \\
$>$ Three & 4 & 3 & 75.0 & $30.0-95.4$ \\
Total & 100 & 12 & 12.0 & $62.5-66.7$ \\
\hline
\end{tabular}

$\mathrm{X}^{2}=37.1 \mathrm{P}=0.00>0.05$

Table 3. Prevalence of T.vaginalis in Relation to marital status.

\begin{tabular}{lllll}
\hline MaritalStatus & No of samples tested & No of positivesamples & Positive (\%) & ConfidenceInterval \\
\hline single & 76 & 10 & 3.6 & $13.2-15.2$ \\
Married & 23 & 2 & 50.0 & $25.4-74.6$ \\
Divorced & 1 & 0 & 75.0 & $30.0-95.4$ \\
Total & 100 & 12 & 12.0 & $62.5-66.7$ \\
\hline
\end{tabular}

$\mathrm{X}^{2}=37.1 \mathrm{P}=0.00>0.05$

\section{Discussion}

The absence of prospective data in well defined populations means that the true dynamics of $T$ vaginalis infection are unknown. Nevertheless, the most striking feature of the epidemiology is the consistently high prevalence found in women in developing and disadvantaged populations.
The effects of $T$ vaginalis on pregnancy outcome have been known for many years [9] and are now receiving increased attention [4]. It is possible that treatment of women with $T$ vaginalis in pregnancy will reduce the incidence of premature rupture of membranes and premature labour [14], although one study has failed to show this [10]. Of course, lowering the risk of infection in the first place through reductions in the community prevalence of the disease is a 
better long term option.

Trichomoniasis is the most common non-viral sexual infection that causes infection in genitourinary tract [14-15]. Infection is mainly transmitted through sexual activity, although non-sexual transmission is also reported [12]. Almost $2 \%-17 \%$ of female infants may be infected by their mothers [13]. In the United States, the prevalence of trichomoniasis has been estimated at $25 \%$ in those referred to STDs clinics and it is higher in certain population groups such as African American women (38\%) [2]. Contrary to some studies which have reported a $25 \%$ or higher infection rate in Africa [2], this study has recorded a lower prevalence of $12 \%$. Although, the prevalence of trichomoniasis in HIVpositive women in Zaire and pregnant women in a rural area in South Africa is estimated to be as high as $38 \%$ and $65 \%$, respectively [11-12]. In Islamic countries, the prevalence of trichomoniasis ranges from $1.2 \%$ in Libya and Jordan, 3.2\% in Turkey to $28.1 \%$ in Saudi Arabia [16-19].

Studies from Africa have suggested that $T$. vaginalis infection may increase the rate of HIV transmission by approximately twofold [10]. Detection and treatment of trichomoniasis may be important strategies in reducing HIV transmission through sexually transmitted infection control. Recommendations for single dose nitroimidazole therapy for all women who have been sexually active at any stage in their life may be appropriate and could be instituted at family planning clinics and other primary healthcare facilities in areas of known high endemic prevalence [10-11]

Studies conducted in Brazil have shown that the prevalence of $\mathrm{T}$. vaginalis infection ranges from $2.6 \%$ [20] to $20 \%$ in women evaluated in primary care centers of different regions of the country [21-24], those living with HIV [25-27], and pregnant women [28]. To improve the infection control, and especially to determine risk factors, some aspects of the approaches should be studied [15]. Thus, given the lack of available data for T. vaginalis infection in Southern Brazil, the present study aimed to identify the risk factors associated with infection, and to investigate the prevalence of the parasite in women of different municipalities in the middle of the southwest region of Rio Grande do Sul State, RS, Brazil [28].

Infection with $T$ vaginalis has been largely ignored by most health professionals since its discovery over 160 years ago but its relative importance is now beginning to be recognized. Control of the disease is dependent on a cheap, safe, and well tolerated antibiotic and should not be ignored.

\section{Conclusion}

In conclusion, the results of this study shows the prevalence of $T$. vaginalis infection in the study population is relatively low and other causes of vaginitis such as bacterial and fungal infections should be given more consideration. Since clinical signs of trichomonal vaginitis are the same of other STDs, a confirmatory laboratory diagnosis is necessary. Further studies in different population groups are needed to determine other aspects of epidemiology of this infection in Iran.

\section{References}

[1] World Health Organization. Global prevalence and incidence of selected curable sexually transmitted diseases: overview and estimates. WHO/GPA/STD/95. Geneva: WHO, 1995.

[2] Heine P, McGregor JA. Trichomonasvaginalis: a reemerging pathogen. ClinObstetGynecol1993; 36: 137-44.

[3] Cotch MF, Pastorek JG, 2nd, Nugent RP, et al. Trichomonasvaginalis associated with low birthweight and preterm delivery. The Vaginal Infections and Prematurity Study Group. Sex TransmDis 1997; 24: 353-60.

[4] terMeulen J, Mgaya HN, Chang-Claude J, et al. Risk factors for HIV infection in gynaecologicalinpatients in Dar es Salaam, Tanzania, 1988-1990. East Afr Med J 1992; 69: 68892.

[5] Laga M, Manoka A, Kivuvu M, et al. Non-ulcerative sexually transmitted diseases as risk factors forHIV-1 transmission in women: results from a cohort study. AIDS 1993; 7: 95-102.

[6] Ghys PD, Diallo MO, Ettiegne-Traore V, et al. Genital ulcers associated with humanimmunodeficiency virus-related immunosuppression in female sex workers in Abidjan, IvoryCoast. J Infect Dis 1995; 172: 1371-4.

[7] Sorvillo F, Kerndt P. Trichomonasvaginalis and amplification of HIV-1 transmission [letter]. Lancet1998; 351: 213-4.

[8] Hardy PH, Hardy JB, Nell EE, et al. Prevalence of six sexually transmitted disease agents arising inpregnant inner-city adolescents and pregnancy outcome. Lancet 1984; 2: 333-7.

[9] Carey JC, Klebanoff MA, Hauth JC, et al. Metronidazole to prevent preterm delivery in pregnantwomen with asymptomatic bacterial vaginosis. National Institute of Child Health and HumanDevelopment Network of Maternal-Fetal Medicine Units [see comments]. N Engl J Med2000; 342: $534-40$.

[10] Ali V, Nozaki T. Current therapeutics, their problems, and sulfur-containing-amino-acidmetabolism as a novel target against infections by "amitochondriate" protozoan parasites.ClinMicrobiol Rev. 2007; 20(1): 164-87.

[11] Schwebke JR, Burgess D. Trichomoniasis. ClinMicrobiol Rev. 2004;17(4):794-803.

[12] Edrissian GH, Rezaeian M, Ghorbani M, Keshavarz H, Mohebali M. 1st ed. Tehran University ofMedical Sciences; 2007. Medical Protozoology.

[13] Petrin D, Delgaty K, Bhatt R, Garber G. Clinical and microbiological aspects of Trichomonasvaginalis. ClinMicrobiol Rev. 1998; 11(2): 300-17.

[14] Khan NA. Emerging Protozoan Pathogenes. 1st ed. Taylor \& Francis group; 2008.

[15] Conrad M, Zubacova Z, Dunn LA, Upcroft J, Sullivan SA, Tachezy J, Carlton JM. Microsatellitepolymorphism in the sexually transmitted human pathogen Trichomonasvaginalis indicates agenetically diverse parasite. Pathogen Trichomonasvaginalis indicates a genetically diverseparasite. MolBiochem Parasitol. 2011; 175: 30-38.

[16] Kassem HH, Majoud OA. Trichomoniasis among women with vaginal discharge in Benghazi city, Libya. J Egypt SocParasitol. 2006; 36(3): 1007-16.]. 
[17] Mahafzah AM, Al-Ramahi MQ, Asa'd AM, El-Khateeb MS. Prevalence of sexually transmittedinfections among sexually active Jordanian females. Sex Transm Dis. 2008; 35(6): 60710

[18] Selvitopu A, Ozcelik S, Degerli S. The incidence of Trichomonasvaginalis in vaginal specimens fromgynecologic patients. TurkiyeParazitolDerg. 2006; 30(3): 175-7.

[19] Madani TA. Sexually transmitted infections in Saudi Arabia. BMC Infect Dis. 2006; 6: 3.

[20] Sutton M, Sternberg M, Koumans EH, McQuillan G, Berman S, Markowitz L. The prevalence ofTrichomonasvaginalis infection among reproductive-age women in the United States, 2001-2004. Clin Infect Dis. 2007; 45: 1319-26.

[21] Lazenby GB, Taylor PT, Badman BS, McHaki E, Korte JE, Soper DE, et al. An association betweenTrichomonasvaginalis and high-risk human papillomavirus in rural Tanzanian womenundergoing cervical cancer screening. ClinTher. 2014; 36: $38-45$.

[22] Miller M, Liao Y, Gomez AM, Gaydos CA, D'Mellow D. Factors associated with the prevalence andincidence of Trichomonasvaginalis infection among African American women in New York citywho use drugs. J Infect Dis. 2008; 197: 503-9.

[23] Simhan HN, Anderson BL, Krohn MA, Heine P, Martinez de
Tejada B, Landers DV, et al. Hostimmune consequences of asymptomatic Trichomonasvaginalis infection in pregnancy. Am JObstetGynecol. 2007; 196: 59.e1-5.

[24] Rocha DA, Filho RA, Mariño JM, dos Santos CM. "Hidden" sexually transmitted infections amongwomen in primary care health services, Amazonas, Brazil. Int J STD AIDS. 2014; 25: 878-86.

[25] Silva LC, Miranda AE, Batalha RS, Monte RL, Talhari S. Trichomonasvaginalis and associatedfactors among women living with HIV/AIDS in Amazonas, Brazil. Braz J Infect Dis.2013; 17: 701-3.

[26] Souza RP, de Abreu AL, Ferreira ÉC, Rocha-Brischiliari SC, de B Carvalho MD, Pelloso SM, et al.Simultaneous detection of seven sexually transmitted agents in human immunodeficiency virus-infected Brazilian women by multiplex polymerase chain reaction. Am J Trop Med Hyg. 2013; 89: 1199-202.

[27] Miranda AE, Pinto VM, Gaydos CA. Trichomonasvaginalis infection among young pregnantwomen in Brazil. Braz J Infect Dis. 2014; 18: 669-71.

[28] Oliveira FA, Pfleger V, Lang K, Heukelbach J, Miralles I, Fraga F, et al. Sexually transmittedinfections, bacterial vaginosis, and candidiasis in women of reproductive age in rural NortheastBrazil: a population-based study. MemInstOswaldo Cruz. 2007; 102: 751-6. 